POHJOISMAINEN YHTEISTYÖ JA KESTÄVÄN KEHITYKSEN 2030-TAVOITTEET

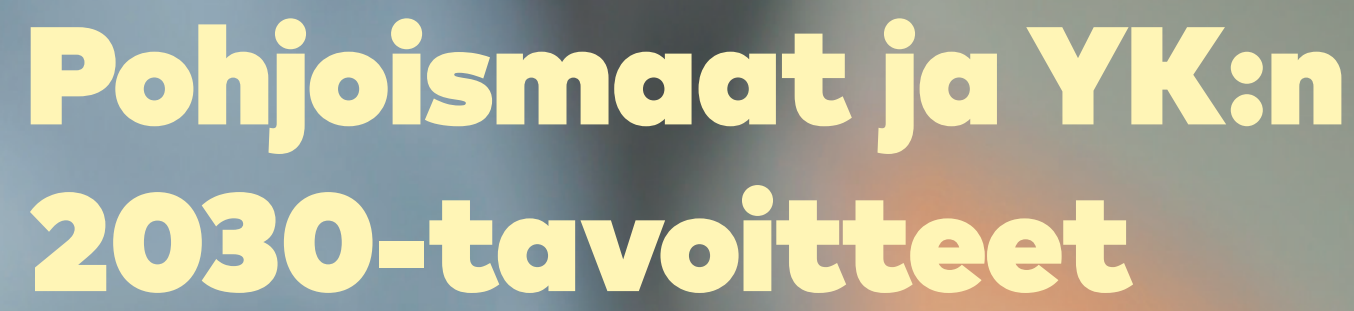




\section{Pohjoismaat ja YK:n 2030-tavoitteet}

Pohjoismainen yhteistyö ja kestävän kehityksen 2030-tavoitteet

- YK:n 2030-tavoitteiden työryhmän laatima Pohjoismaiden neuvoston raportti

ANP 2017:774

ISBN 978-92-893-5220-8 (PRINT)

ISBN 978-92-893-5221-5 (PDF)

ISBN 978-92-893-5222-2 (EPUB)

http://dx.doi.org/10.6027/TN2017-774

(C) Pohjoismaiden neuvosto 2017

Kannen valokuva: Unsplash

Ulkoasu: Mette Agger Tang

Paino: Rosendahls

Printed in Denmark

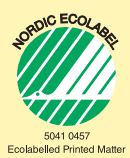

\section{Pohjoismainen yhteistyö}

Pohjoismainen yhteistyö on yksi maailman laajimmista alveellisista yhteistyömuodoista. Yhteistyön piiriin kuuluvat Islanti, Norja, Ruotsi, Suomi ja Tanska sekä Ahvenanmaa, Färsaaret ja Grönlanti.

Pohjoismaista yhteistyötä tehdään politiikan, talouden ja kulttuurin aloilla tärkeänä osana eurooppalaista ja kansainvälistä yhteistyötä. Pohjoismaisen yhteisön tavoitteena on vahva Pohjola vahvassa Euroopassa.

Pohjoismainen yhteistyö pyrkii vahvistamaan pohjoismaisia ja alveellisia etuja ja arvoja globaalissa maailmassa. Maiden yhteiset arvot lujittavat osaltaan Pohjolan asemaa yhtenä maailman innovatiivisimmista ja kilpailukykyisimmistä alveista.

\section{Pohjoismaiden neuvosto}

Nordens Hus

Ved Stranden 18

1061 København K

www.norden.org

Pohjoismaisia julkaisuja voi ladata osoitteesta: www.norden.org/nordpub 
POHJOISMAINEN YHTEISTYÖ JA KESTÄVÄN KEHITYKSEN 2030-TAVOITTEET

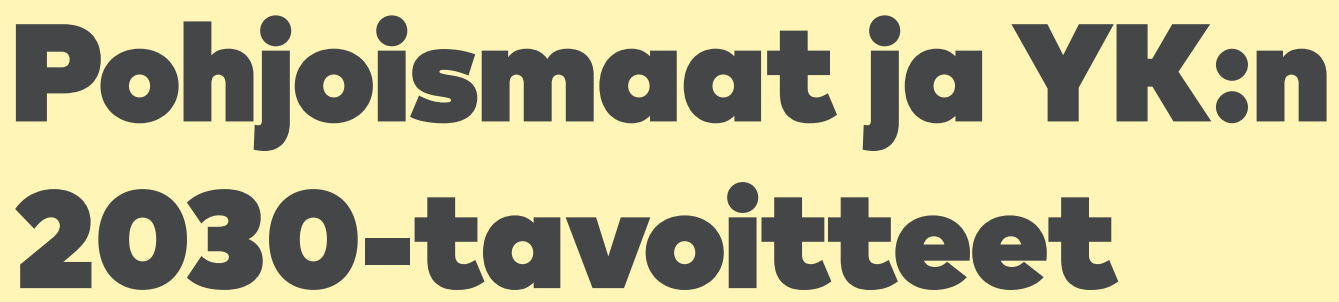




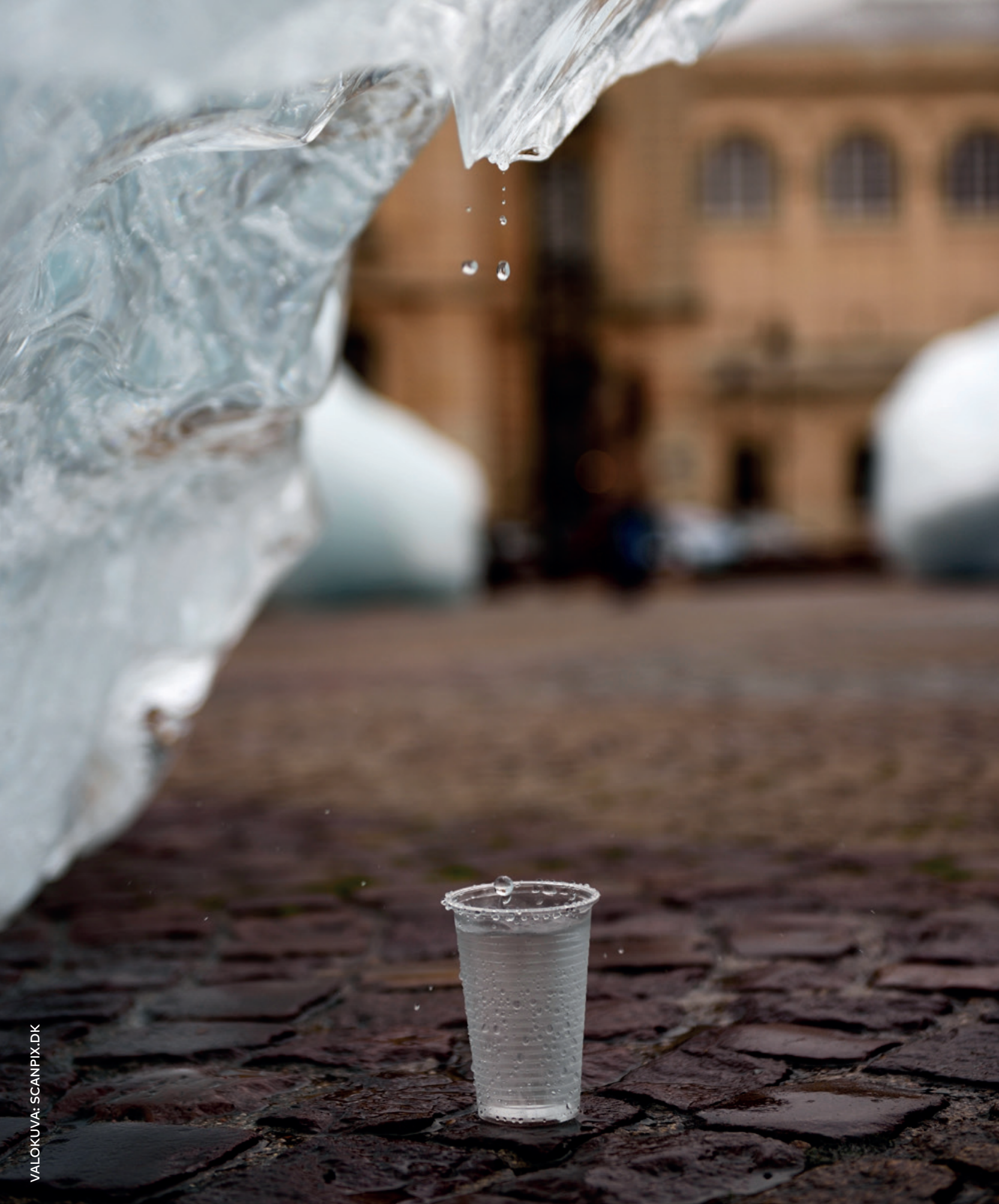




\section{Sisällys}

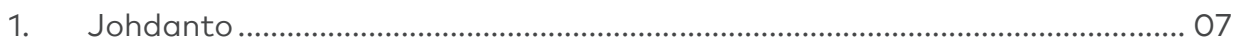

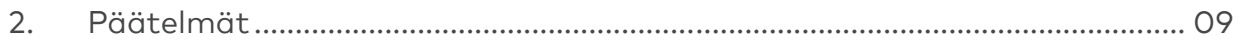

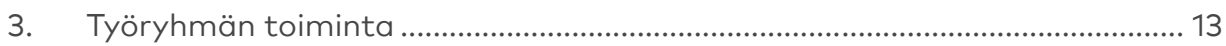

4. YK:n 2030-tavoitteet ja Pohjoismaiden poliittiset tavoitteet.......................... 15

5. Pohjoismaiden toimet $\mathrm{YK}: \mathrm{n}$ 2030-tavoitteiden saavuttamiseksi................... 17

6. Pohjoismaiden ministerineuvoston työ kestävän kehityksen tavoitteiden parissa ........................................................................ 21

7. YK:n 2030-tavoitteet yhteispohjoismaisina tavoitteina .................................. 22

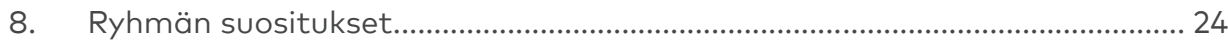

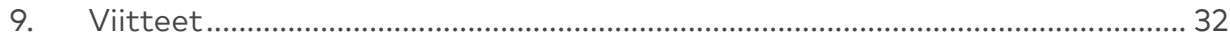

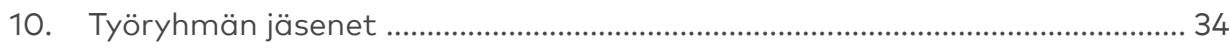




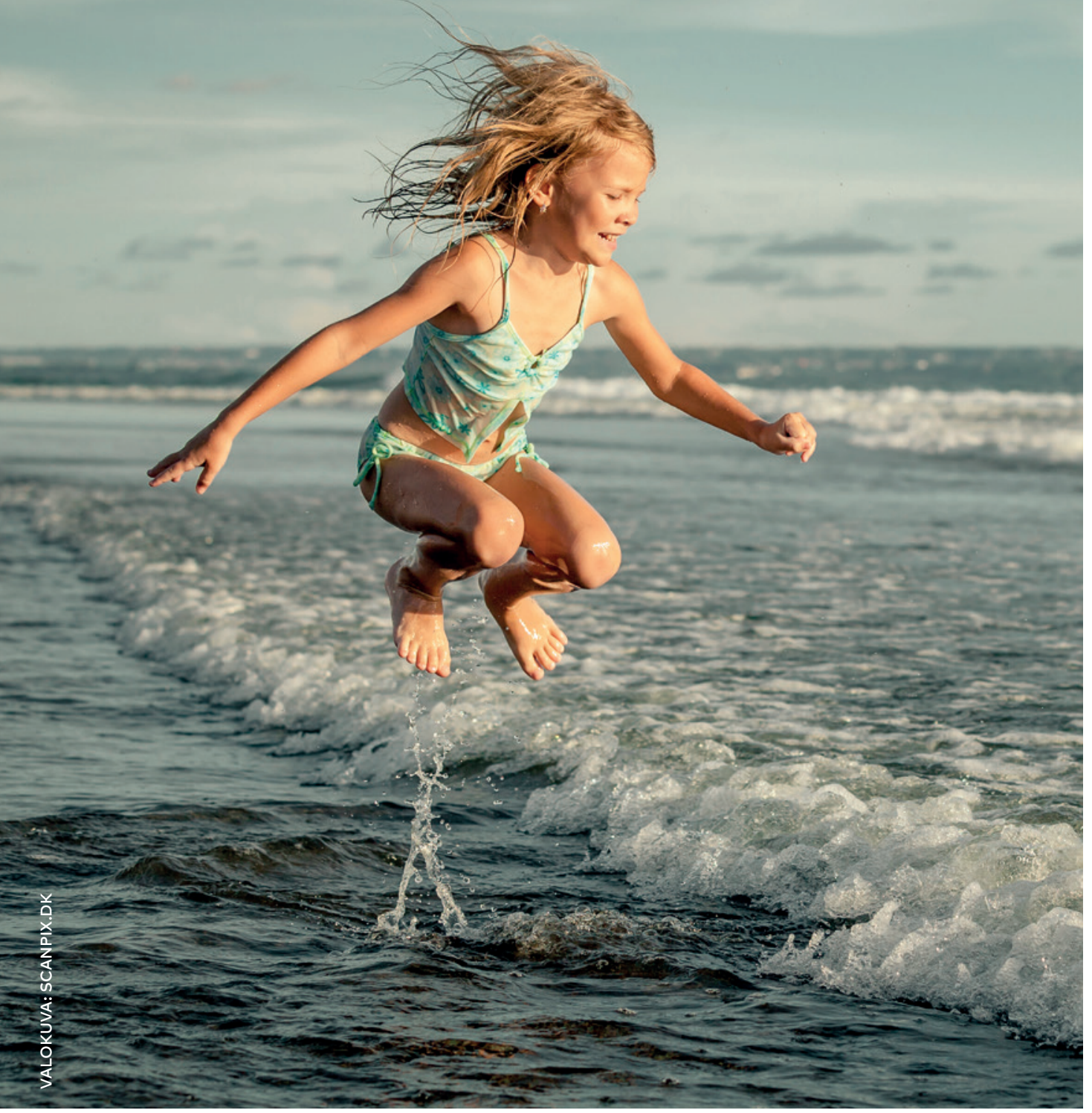




\section{Johdanto}

Syyskuussa 2015 YK hyväksyi kestävän kehityksen 17 tavoitetta, jotka pyritään saavuttamaan vuoteen 2030 mennessä. ${ }^{1}$ 17 yleistavoitetta (goals) on jaettu 169 alatavoitteeseen (targets), joista monet ovat konkreettisempia ja helpommin mitattavissa. Toisin kuin aiemmat kestävän kehityksen vuosituhattavoitteet, uudet tavoitteet ovat universaaleja ja koskevat kaikkia maita. Monet konkreettisista tavoitteista on tarkoitus saavuttaa aiemmin, joko vuoteen 2020 tai 2025 mennessä.

Päävastuu kunnianhimoisen suunnitelman toteuttamisesta paremman maailman saavuttamiseksi on yksittäisillä valtioilla. Suosituksena on, että kukin maa laatii oman strategiansa sekä sen rahoitussuunnitelman. Kuten raportin 5. luvusta käy ilmi, joidenkin Pohjoismaiden suunnitelmat ovat jo valmiina ja toisten parhaillaan tekeillä.

Syksyllä 2016 Pohjoismaiden neuvosto päätti asettaa valiokuntien ja puheenjohtajiston edustajista koostuvan työryhmän tarkoituksena selvittää Pohjoismaiden neuvoston edellytyksiä edistää YK:n kestävän kehityksen tavoitteiden toteuttamista, ja lisäksi laatia sitä koskevia ehdotuksia. Ryhmälle annettiin myös tehtäväksi käydä läpi Pohjoismaiden ministerineuvoston suunnitelmat ja kerätä puolveryhmiltä sekä kansalaisyhteiskunnan ja elinkeinoelämän edustajilta ehdotuksia siitä, miten pohjoismaisen yhteistyön kautta parhaiten voidaan osallistua kestävän kehityksen tavoitteiden toteuttamiseen. Ryhmän oli tarkoitus selvittää, voidaanko pohjoismaisessa yhteistyössä tukea kansainvälistä panostusta tavoitteiden saavuttamiseksi, ja jos näin on, niin millä tavoin. ${ }^{2}$

Työryhmän tehtävänä oli selkeyttää sitä, minkä tavoitteiden parissa Pohjoismaat voivat tehdä yhteistyötä ja mitä toimia voitaisiin käynnistää tavoitteiden saavuttamiseksi.

Pohjoismaiden ministerineuvosto päätti vuonna 2016 käynnistää ohjelman, jolla tuetaan YK:n kestävän kehityksen tavoitteiden toteuttamista Pohjoismaissa. Asiaa käsittelevä ministerineuvoston ehdotus esitellään Helsingin-istunnossa marraskuussa 2017. Tämä raportti voi tarjota ideoita työhön Pohjoismaiden ministerineuvoston ohjelman sekä ministerineuvoston ehdotuksen käsittelyn parissa. Lisäksi raportissa tuodaan esille, miten Pohjoismaiden neuvosto voi omassa työssään edistää YK:n kestävän kehityksen tavoitteita. 


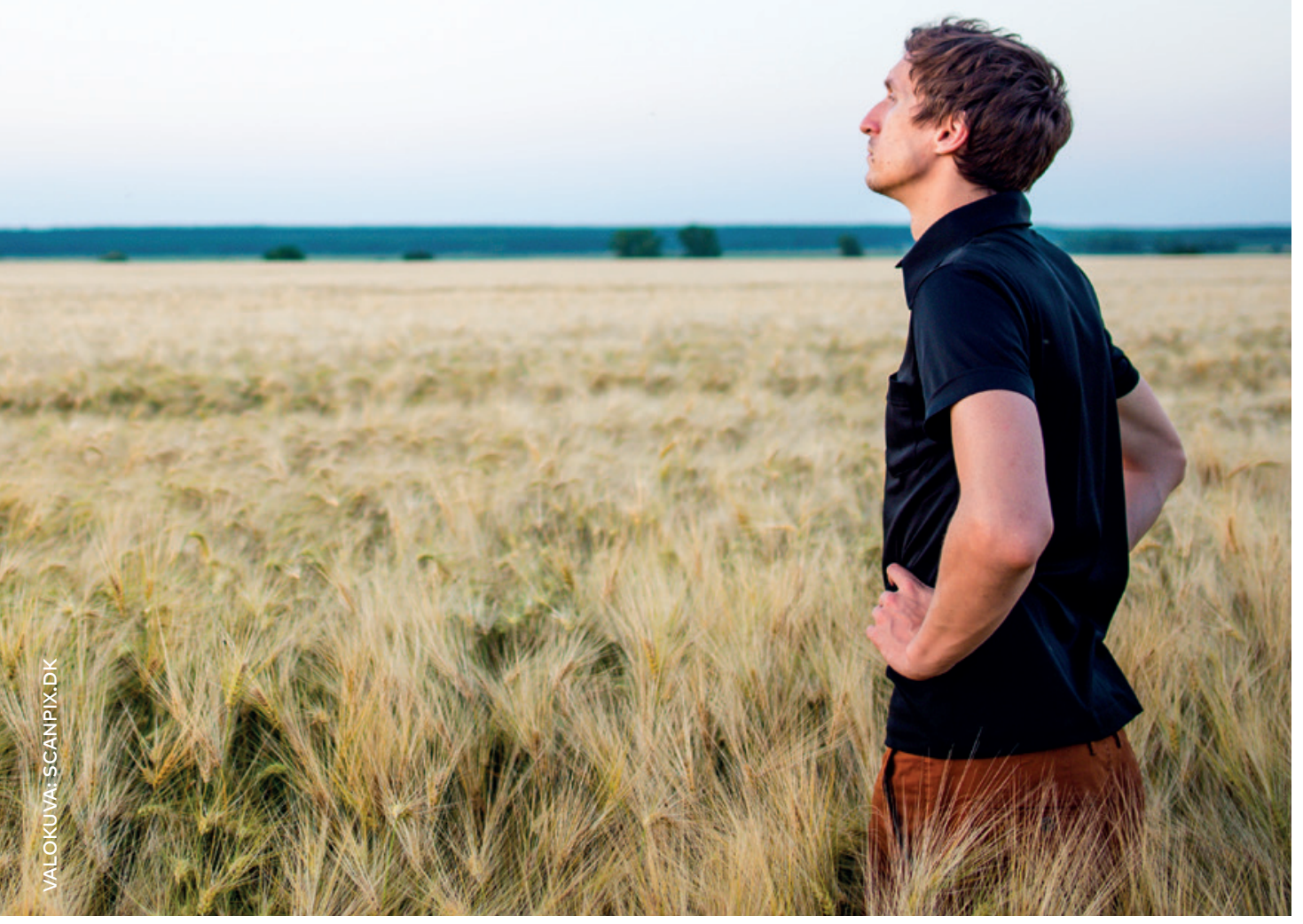




\section{Päätelmät}

Työryhmä suosittelee, että Pohjoismaiden neuvosto ja Pohjoismaiden ministerineuvosto tekevät aktiivista seurantatyötä kestävän kehityksen tavoitteiden parissa vuoteen 2030 asti ja ottavat ne pysyväksi kohdaksi työsuunnitelmiinsa koko kauden ajaksi työn jatkuvuuden ja pitkäjänteisyyden turvaamiseksi.

Pohjoismaiden neuvoston sisäisen työn osalta ryhmä antaa seuraavat suositukset:

- Valiokunnat jakavat keskenään vastuun tavoitteiden seuraamisesta ja Pohjoismaiden neuvoston sihteeristö varmistaa, että aihe sisällytetään vuotuisiin työsuunnitelmiin. (Katso kohta 8 a1.)

- Valiokunnat raportoivat vuosittain työstään kestävän kehityksen tavoitteiden parissa ja raportit esitellään puheenjohtajiston joulukuun kokouksessa. Puheenjohtajisto tekee tarvittaessa seurantaa valiokuntien raporteista yhteistyöministerien tai vaihtoehtoisesti pääministerien kanssa säännöllisesti pidettävissä kokouksissa ja tuo seurantaan liittyvät asiat esille budjettiprosessin yhteydessä. (Katso kohta 8 a1.)

- Pohjoismaiden neuvoston kansallisia valtuuskuntia kehotetaan jatkossa ottamaan huomioon kestävän kehityksen tavoitteet puheenjohtajakauden priorisoinneista päätettäessä. (Katso kohta 8 a1.)
- Kaikissa jäsenehdotuksista ja ministerineuvoston ehdotuksista laadittavissa mietinnöissä selvitetään, liittyykö ehdotus yhteen tai useampaan kestävän kehityksen tavoitteeseen tai alatavoitteeseen. Jos näin on, otetaan kantaa siihen, voidaanko suosituksen toteuttamisen olettaa edistävän tai hankaloittavan kyseisen tavoitteen toteutumista. (Katso kohta 8 a2.)

- Pohjoismaiden neuvosto edistää kestävän kehityksen tavoitteiden ottamista muiden kansainvälisten foorumien ja kansallisten parlamenttien asialistalle. (Katso kohta 8 a3.)

- Pohjoismaiden neuvosto tekee aloitteen pohjoismaisesta pyöreän pöydän konferenssista, jossa Pohjoismaiden parlamenttien jäsenet vaihtavat tietoa ja ajatuksia parlamenttien roolista kestävän kehityksen tavoitteiden toteuttamisessa. (Katso kohta 8 a3.)

Ryhmä katsoo, että raportin ehdotukset tulee tarvittavilta osin kytkeä Pohjoismaiden neuvoston tulevaan kansainväliseen strategiaan.

Pohjoismaiden ministerineuvoston työn osalta ryhmä antaa seuraavat suositukset:

- Kaikki asianomaiset elinkeinoelämän parissa työskentelevät pohjoismaiset laitokset, esimerkiksi Pohjoismainen 
energiantutkimus (NEF), Nordic Innovation, Pohjoismaiden ympäristörahoitusyhtiö (NEFCO) ja NordForsk, selvittävät tulevaa työtä suunnitellessaan, miten ne voisivat tukea kestävän kehityksen tavoitteiden toteutumista. Lisäksi tulee selvittää, olisiko ruotsalaisessa Swedish Leadership for Sustainable Development -aloitteessa (SLSD) ja YK:n kehitysohjelman Sustainable Development Goals Accelerator - aloitteessa (SDGA) aineksia pohjoismaisiksi tai Pohjoismaiden tukemiksi hankkeiksi. (Katso kohta 8 b1.)

- Pohjoismaiden ministerineuvosto perustaa yhteistyössä Pohjoismaiden neuvoston kanssa foorumin, jossa poliitikot ja tutkijat käyvät säännöllisesti vuoteen 2030 asti vuoropuhelua ratkaisuista, jotka edistävät kestävän kehityksen tavoitteiden saavuttamista ja jotka pohjautuvat kaikkien eri Pohjoismaiden tutkimukseen ja tietotaitoon. (Katso kohta 8 b2.)

- Pohjoismaiden ministerineuvosto pitäytyy Hyvä elämä kestävässä Pohjolassa -strategian tavoitteissa ja täydentää niitä sellaisilla YK:n 2030-tavoitteilla, jotka Pohjoismaat ovat valinneet yhteisiksi pohjoismaisiksi tavoitteiksi. Nykyiset kestävän kehityksen indikaattorit käydään läpi. Siltä osin kuin soveltuvia indikaattoreita ei ole, Pohjoismaiden tilastokeskuksille annetaan tehtäväksi kehittää tarvittavien tilastojen kokoamista ja työstämistä, jotta voidaan seurata kehitystä yhteisten pohjoismaisten tavoitteiden osalta. (Katso kohta 8 b3.)

- Pohjoismaiden ministerineuvosto antaa säännöllisesti selonteon Pohjoismaiden neuvostolle siitä, osoittavatko kestävän kehityksen indikaattorit Pohjoismaiden olevan menossa oikeaan suuntaan tavoitteiden toteuttamisessa. (Katso kohta 8 b3.)

- Laaditaan säännöllisesti arviointi muutoksista ja eroavaisuuksista lasten elinoloissa Pohjoismaissa. (Katso kohta 8 b4.)

- Selvitetään edellytyksiä saada aikaiseksi kolmikantakeskustelua pohjoismaisella tasolla. (Katso kohta 8 b5.)

- Välitetään tietoa ja kokemuksia parhaista käytännöistä sekä Pohjoismaiden kesken että kansainvälisesti. (Katso kohta 8 b6.)

- Pohjoismaiden ministerineuvosto jakaa tietoa kestävän kehityksen tavoitteista ja niiden tärkeydestä Pohjoismaiden kansalaisille järjestämällä aloitteita pohjoismaisten kansalaistoimijoiden, kuten YK-liittojen ja Norden-yhdistysten, kanssa.

(Katso kohta 8 b7.)

Pohjoismaiden hallitusten osalta ryhmä antaa seuraavat suositukset:

- Pohjoismaiden Investointipankille (NIB), Pohjoismaiden kehitys- 
rahastolle (NDF) ja Pohjoismaiden ympäristörahoitusyhtiölle (NEFCO) annetaan selkeät valtuudet edistää kestävän kehityksen tavoitteiden toteuttamista. Lisäksi selvitetään, voitaisiinko kyseisten toimijoiden potentiaalia hyödyntää paremmin lisäämällä niiden välistä yhteistyötä tai yhdistämällä ne. (Katso kohta 8 b8.)
- Pohjoismaat puhuvat yhdellä äänellä kestävän kehityksen tavoitteista YK:ssa, EU:ssa ja muilla kansainvälisillä foorumeilla. (Katso kohta 8 C.)

Ehdotuksia kuvaillaan tarkemmin 8. luvussa.

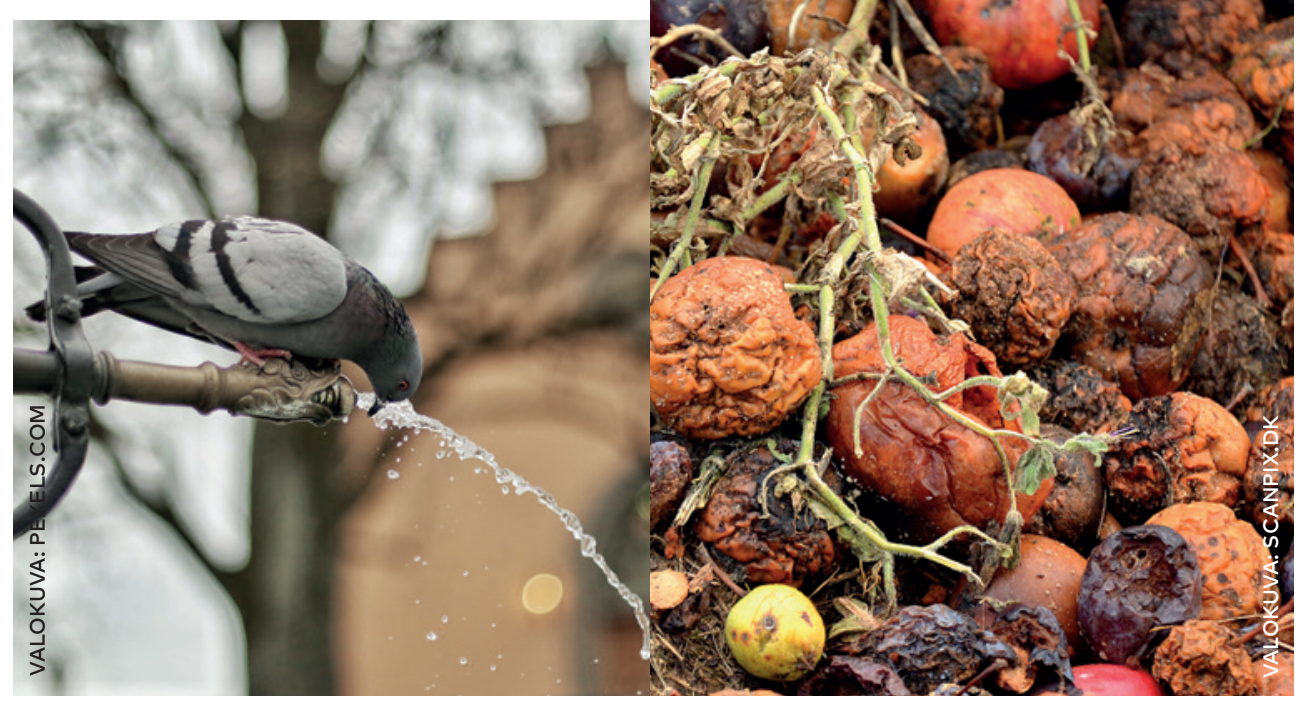




\section{Työryhmän toiminta}

Työryhmän jäsenet nimettiin syksyllä 2016 ja ryhmä järjestäytyi Oslossa

25. tammikuuta 2017 pidetyssä kokouksessa Pohjoismaiden neuvoston kokousten yhteydessä.

Työryhmän valtuuttamana ryhmän puheenjohtaja Sonja Mandt tapasi eri järjestöjen edustajia kuullakseen pohjoismaiseen yhteistyöhön kohdistuvista odotuksista YK:n kestävän kehityksen tavoitteiden osalta:

- Norjan tilastokeskus: Live Margrethe Rognerud ja Elisabeth Nørgaard

- Norjan luonnonsuojeluliitto: Maren Aschehough Esmark ja Jorun Valstad

- Norjan työnantajien keskusjärjestö (NHO): Hege Araldesen ja Jon Vea

- Norjan YK-liitto: Anne Cathrine da Silva, Rune Arctander ja Ingunn Eck

- Pohjolan ammatillinen yhteisjärjestö (PAY): Magnus Gissler, Ragnhild Lied, Arne Grevsen, Bente Sorgenfrey, Lars Qvistgaard, Maria Häggman ja José Pérez Johansson

- Norden-yhdistysten liitto:

Henrik Wilén
- Tanskan Unicef: Steen Andersen ja Line Grove Hermansen

- Pohjoismaiden YK-liitot ja YK:n Kööpenhaminan-edustusto: Torleif Jonasson, Camilla Brückner, Pernille Fenger, Anne Poulsen, Asger Ryhl, Eva Egesborg, Trine Lise Sundnes, Anne Cathrine da Silva, Jens Petersson, Helena Laukko, Hildur Baldvinsdóttir ja Jørgen Estrup.

Ahvenanmaan Natur och miljö -yhdistys, Tanskan AIDS-rahasto ja Pohjoismaiden YK-liitot ovat virallisissa yhteydenotoissaan esittäneet ehdotuksia Pohjoismaiden yhteisiksi toimiksi.

Työryhmä piti toisen kokouksensa Tukholmassa 4. huhtikuuta Pohjoismaiden neuvoston kokousten yhteydessä. Ryhmän kolmas kokous pidettiin 1. kesäkuuta Oslossa, minkä jälkeen raporttiluonnos toimitettiin Pohjoismaiden neuvoston valiokunnille ja puolveryhmille kommentoitavaksi.

Pohjoismaiden neuvoston sihteeristön vanhempi erityisasiantuntija Tryggvi Felixson on toiminut ryhmän sihteerinä. 


\section{YK:n 2030-tavoitteet ja Pohjoismaiden poliittiset tavoitteet}

Kestävän kehityksen tavoitteiden taustalla ovat YK:n vuosituhattavoitteista (Millennium Development Goals, MDG) saadut myönteiset kokemukset. Vuosituhattavoitteiden parissa tehdystä työstä kertyneitä kokemuksia pidetään todisteena siitä, että yhteisistä maailmanlaajuisista toimista voidaan saada myönteisiä tuloksia. Uudet kestävän kehityksen tavoitteet (Sustainable Development Goals, SDG) ovat vuosituhattavoitteita laaja-alaisempia. Niiden myötä ekologia, maapallon elämän edellytykset, asetetaan rinnakkain vuosituhattavoitteiden perustana olleen sosiaalisen ja taloudellisen ulottuvuuden kanssa.

YK:n 2030-tavoitteet ovat laaja kestävän kehityksen toimintaohjelma, koko inmiskunnalle laadittu maailmanlaajuinen suunnitelma. Tavoitteet pohjautuvat visioon sosiaalisesta ja taloudellisesta muutoksesta, jonka myötä maailman 7,5 miljardin väestö saisi yhä enemmän oikeudenmukaisuutta, laajan pääsyn välttämättömiin ja elintärkeisiin hyödykkeisiin ja onnistuisi välttämään elämän edellytysten tuhoutumisen maapallolla.

Uudet kestävän kehityksen tavoitteet ovat laajalti tulosta Pohjoismaiden viime vuosikymmeninä YK:ssa esittämistä asioista sekä maiden oman kehitys- ja ulkopolitiikan toimista. Tämän seurauksena Pohjoismailla onkin erityinen vastuu tavoitteiden toteuttamisesta sekä Pohjoismaissa että maailmalla. Siksi Pohjoismaiden tulee yhteistyössään pyrkiä edistämään kestävän kehityksen tavoitteiden toteutumista, mikä käytännössä luo parempaa tulevaisuutta koko ihmiskunnalle ja maapallolle. Tämä kahtalainen vastuu merkitsee sitä, että Pohjoismaat tukevat uusien tavoitteiden mukaista kestävää kehitystä sekä Pohjoismaissa että maailmalla.

Pohjoismaiden tilanne on onneksi melko hyvä kestävän kehityksen tavoitteiden saavuttamiseksi, ja mailla on sekä ideoita että käytännön ratkaisuja, joista voi olla hyötyä myös eri puolilla maailmaa. On tärkeää kasvattaa tietoisuutta asiasta Pohjoismaissa. Pohjoismaiden kansalliset parlamentit voivat edistää kunnianhimoisten standardien tai vertailuarvojen asettamista työn täytäntöönpanolle. Pohjoismaiden neuvosto voi pitää asiaa esillä, edistää sitä koskevaa tietoisuutta sekä kannustaa Pohjoismaita käytännön yhteistyöhön kestävän kehityksen tavoitteiden parissa Pohjoismaiden ministerineuvoston kautta. 


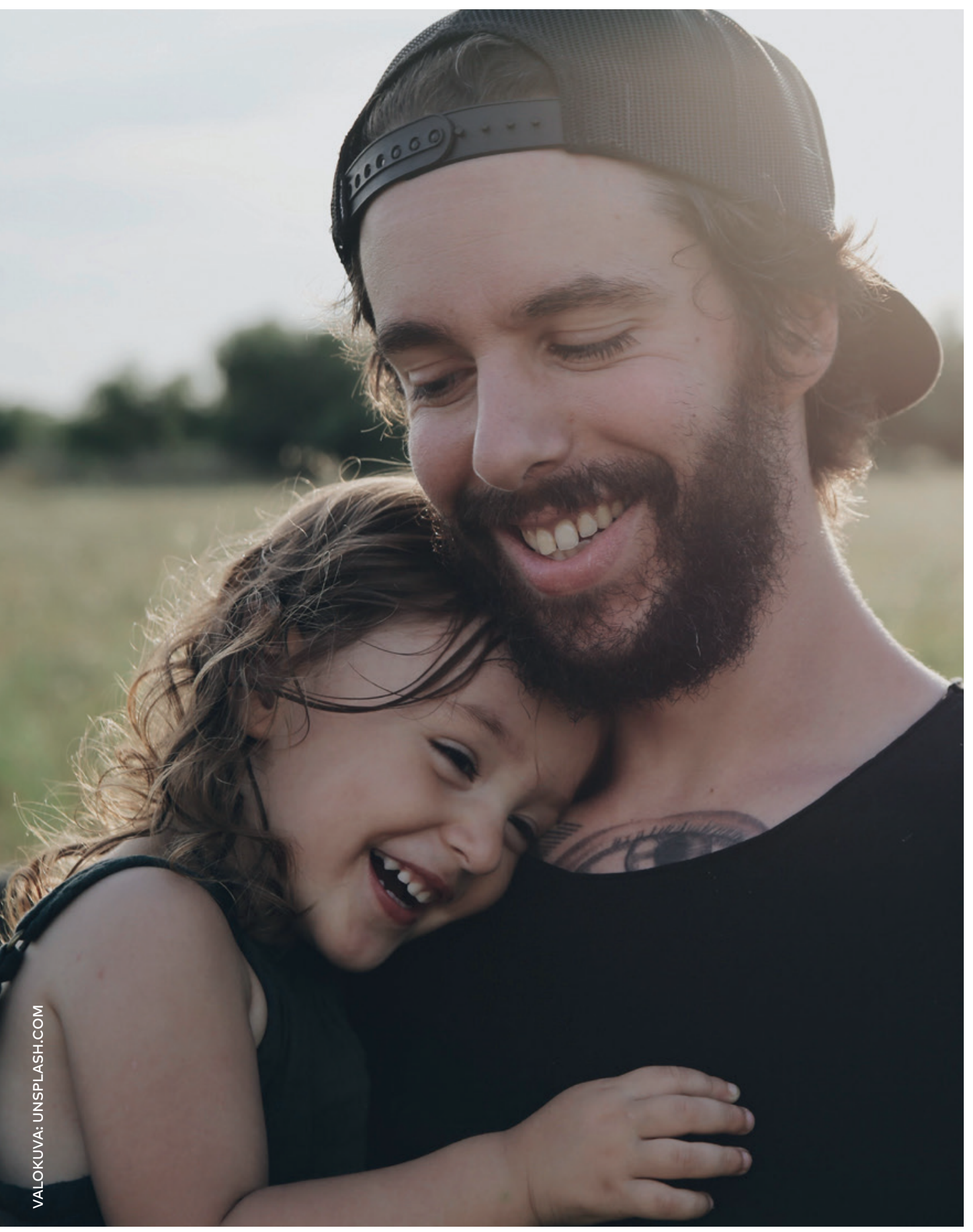




\section{Pohjoismaiden toimet YK:n 2030-tavoitteiden saavuttamiseksi ${ }^{3}$}

Tanskan hallitus esitteli maaliskuussa 2017 kestävän kehityksen tavoitteita koskevan toimintasuunnitelman. Suunnitelman tarkoituksena on edistää yhtenäistä työtä kestävän kehityksen tavoitteiden saavuttamiseksi. Ajatuksena on, että kaikki lakiehdotukset arvioidaan kestävän kehityksen tavoitteiden näkökulmasta, ja sama koskisi kaikkia ehdotuksia EU-lainsäädännöksi. Hallitus raportoi vuosittain työn etenemisestä. Suunnitelmassa on yhteensä 37 tavoitetta, jotka jakautuvat neljälle painopistealueelle: kasvu ja hyvinvointi, inmiset, ympäristö ja ilmasto sekä rauhalliset ja turvalliset yhteiskunnat. Jokaiselle 37 tavoitteelle on asetettu indikaattorit. Suunnitelmassa arvioidaan köyhyyden, eriarvoisuuden ja työttömyyden tavoitteiden olevan vähemmän keskeisellä sijalla. Suunnitelma määrittelee puitteet hallituksen työlle ja painopisteille. Hallituksen pyrkimyksenä on myös luoda suunnitelman avulla lähtökohta toimille ja kumppanuuksille Tanskan yhteiskunnan eri osien välillä.

Valtiovarainministeriö ja ulkoasiainministeriö vastaavat työn koordinoinnista. Kestävän kehityksen tavoitteiden edistämistyöhön ei ole perustettu erityistä järjestelmää hallituksen ja kansalaisyhteiskunnan vuorovaikutukselle.

Suomen hallitus on vuoden 2017 alussa hyväksynyt vuoteen 2050 ulottuvan
Suomi, jonka haluamme 2050 -yhteiskuntasitoumuksen. Se pohjautuu yli 20 vuoden kokemukseen kestävän kehityksen kansallisista strategioista. Suunnitelmaa ei ole suunnattu ainoastaan hallitukselle, vaan myös lähemmäs 300 kansalaisyhteiskunnan toimijaa on ilmaissut tukensa ja halunsa osallistua työn toteuttamiseen. Kyseessä on pitkän aikavälin suunnitelma, jonka tavoitteena on muun muassa ehkäistä sitä, että hallituksen vaihdokset eduskuntavaalien yhteydessä neljän vuoden välein aiheuttaisivat sekaannusta. Suunnitelmassa on kahdeksan yleistavoitetta: hyvinvointi, kansalaisten osallistaminen, kestävää kehitystä tukeva työ, kestävät yhdyskunnat, hiilineutraali yhteiskunta, resurssien viisas käyttö, kestävää kehitystä tukevat elämäntavat ja kestävään kehitykseen pohjautuvat päätökset. Tavoitteisiin pohjautuvan kehityksen seuraamisen indikaattoreita laaditaan parhaillaan.

Yleisen tason ohjausvastuu on kansallisella toimikunnalla, jota johtaa Suomen pääministeri. Seurannan ja täytäntöönpanon osalta työssä avustaa laajalti eri tieteenaloja edustava kahdeksanjäseninen asiantuntijapaneeli sekä ryhmä, jonka jäseninä on poliittisten puolveiden ja kansalaisyhteiskunnan edustajia. Kehityspoliittinen toimikunta on osa täytäntöönpanon organisaatiorakennetta. Suomen eduskunnan jäsenet ovat edustettuina sekä kansallisessa kestävän 
kehityksen toimikunnassa että kehityspoliittisessa toimikunnassa.

Suomi toimitti ensimmäisen kansallisen raporttinsa YK:Ile vuonna $2016 .{ }^{4}$

Islanti ei ole laatinut suunnitelmaa YK:n kestävän kehityksen tavoitteiden kansallisesta seurannasta. Vuonna 2011 hallitus hyväksyi osaamista, kestävää kehitystä ja hyvinvointia koskevan poliittisen strategian, jossa määritellään 20 tavoitetta vuoteen 2020 mennessä. YK:n kestävän kehityksen tavoitteita koskeva suunnitelma saadaan oletettavasti hyväksyttyä vuoden 2017 aikana ja täytäntöönpano alkaa vuonna 2018. Ajatuksena on, että pääministerin kanslia koordinoi suunnitelman parissa tehtävää työtä.

Norjan hallitus on nimittänyt vastuuministeriön kullekin 17:Ile kestävän kehityksen tavoitteelle. Ministeriöt raportoivat budjettiasiakirjoissaan vastuulleen kuuluvien tavoitteiden seurannasta. Kukin ministeriö raportoi vastuullaan olevien alatavoitteiden seurannasta osana ministeriön yleistä toimintaa. Valtiovarainministeriö kokoaa pääkohdat valtion tulo- ja menoarvioon. Ulkoasiainministeriö koordinoi seurantaa kansainvälisellä tasolla. Työn osana on laadittu kooste tavoitteista, joiden saavuttamista pidetään vaikeana Norjalle. Tarvittavia indikaattoreita ollaan parhaillaan etsimässä ja kehittämässä. Valtiovarainministeriö laatii koosteraportin, joka sisältyy kunkin vuoden budjettiesitykseen. ${ }^{5}$ Kestävän kehityksen tavoitteiden edistämistyöhön ei ole perustettu erityistä järjestelmää hallituksen ja kansalaisyhteiskunnan vuorovaikutukselle. Useat kansalaisjärjestöt ovat kehitys- ja ympäristöverkosto ForUMin koordinoimana koonneet voimansa ja esittäneet konkreettisia ehdotuksia siitä, miten Norja voi saavuttaa tavoitteensa. Norjan ulkoasiainministeriö esitteli huhtikuussa 2017 hallituksen selonteon suurkäräjille kestävän kehityksen tavoitteista ja Norjan kehityspolitiikasta otsikolla Yhteinen vastuu yhteisestä tulevaisuudesta.

Norja toimitti ensimmäisen kansallisen raporttinsa YK:Ile vuonna $2016 .{ }^{6}$

Ruotsin hallitus ilmoitti maaliskuussa 2016, että Ruotsin tavoitteena on johtoasema kestävän kehityksen tavoitteiden toteuttamisessa. Ruotsi on perustanut eri osaamisalojen ja organisaatioiden edustajista koostuvan seitsenjäsenisen komitean, Agenda 2030 -valtuuskunnan. Lisäksi on perustettu ministeriöiden välinen työryhmä, ja kaikkia julkisia laitoksia on kehotettu arvioimaan YK:n kestävän kehityksen tavoitteiden vaikutuksia niiden omaan toimintaan. Päävastuussa olevat valtiovarainministeriö ja ulkoasiainministeriö ovat perustaneet sihteeristön yhdessä energia- ja ympäristöministeriöiden kanssa. Komitea toimitti 1. kesäkuuta 2017 raporttinsa, ${ }_{1}^{7}$ joka sisältää ehdotukset toimintasuunnitelmaksi ja priorisoiduiksi tavoitteiksi. Komitea antaa konkreettisia toimia koskevan ehdotuksen vuonna 2018. Kehityspolitiikkaa päivitetään myös niin, että siinä otetaan huomioon YK:n 
2030-tavoitteet. Ruotsi on lisäksi perustanut kestävän kehityksen tiedeneuvoston tukemaan prosessin toteutusta. Stockholm Environment Institute -tutkimuslaitoksen (SEI) mukaan YK:n 169 alatavoitteesta 70:tä ei ole toteutettu kokonaisuudessaan Ruotsissa.

Ruotsi esitteli ensimmäisen kansallisen raporttinsa YK:Ile kesäkuussa $2017 .{ }^{8}$

Färsaarilla ulkoasiainministeriö on käynnistänyt prosessin, jonka odotetaan johtavan YK:n 2030-tavoitteiden kansallisen suunnitelman laatimiseen.

Grönlannissa hallitus hyväksyi kestävän kehityksen ja kasvun ohjelman. Suunnitelman päätavoitteena on parantaa Grönlannin talouden riippumattomuutta ja yhteiskunnan kestävyyttä. Valtiovarainministeriöllä on päävastuu suunnitelmasta, joka sisältää useita kestävän kehityksen tavoitteisiin kytkeytyviä osa-alueita. Hallitus on laatinut analyysin kestävän kehityksen tavoitteiden jakautumisesta eri julkisten laitosten ja organisaatioiden toimialoille.

Ahvenanmaalla on pitkät perinteet kestävän kehityksen suunnitelmien toteuttamisessa kansalaisyhteiskuntaa laajasti osallistaen. YK:n 2030-tavoitteiden seurantana avoimessa prosessissa on laadittu uusi erityisesti seitsemään tavoitteeseen keskittyvä suunnitelma, joka hyväksyttiin vuonna 2016. Tavoitteille ollaan parhaillaan laatimassa indikaattoreita.
Yleisesti voidaan todeta, että kaikilla Pohjoismailla on konkreettisia tavoitteita kestävän kehityksen seurannalle. Norja, Ruotsi, Suomi, Tanska ja Ahvenanmaa ovat koosteen mukaan päässeet pitkälle toteutuksen suunnittelussa ja rakenteessa, ja prosessi on käynnissä muissa maissa. Toteutustapa ja menetelmät vaihtelevat eri maiden välillä. Useimpien maiden suunnitelmien odotetaan priorisoivan tiettyjä 2030-tavoitteita ja seuraavan näiden kehitystä raportoinnin ja indikaattorien avulla. Norjan, Ruotsin ja Suomen parlamentit ovat saaneet tehtäväksi joko osallistua suunnitelmien laadintaan tai seurannan valvontaan. Kansalaisyhteiskunnan osallistumista on korostettu Suomen ja Ahvenanmaan, mutta ei varsinaisesti muiden maiden suunnitelmissa. 


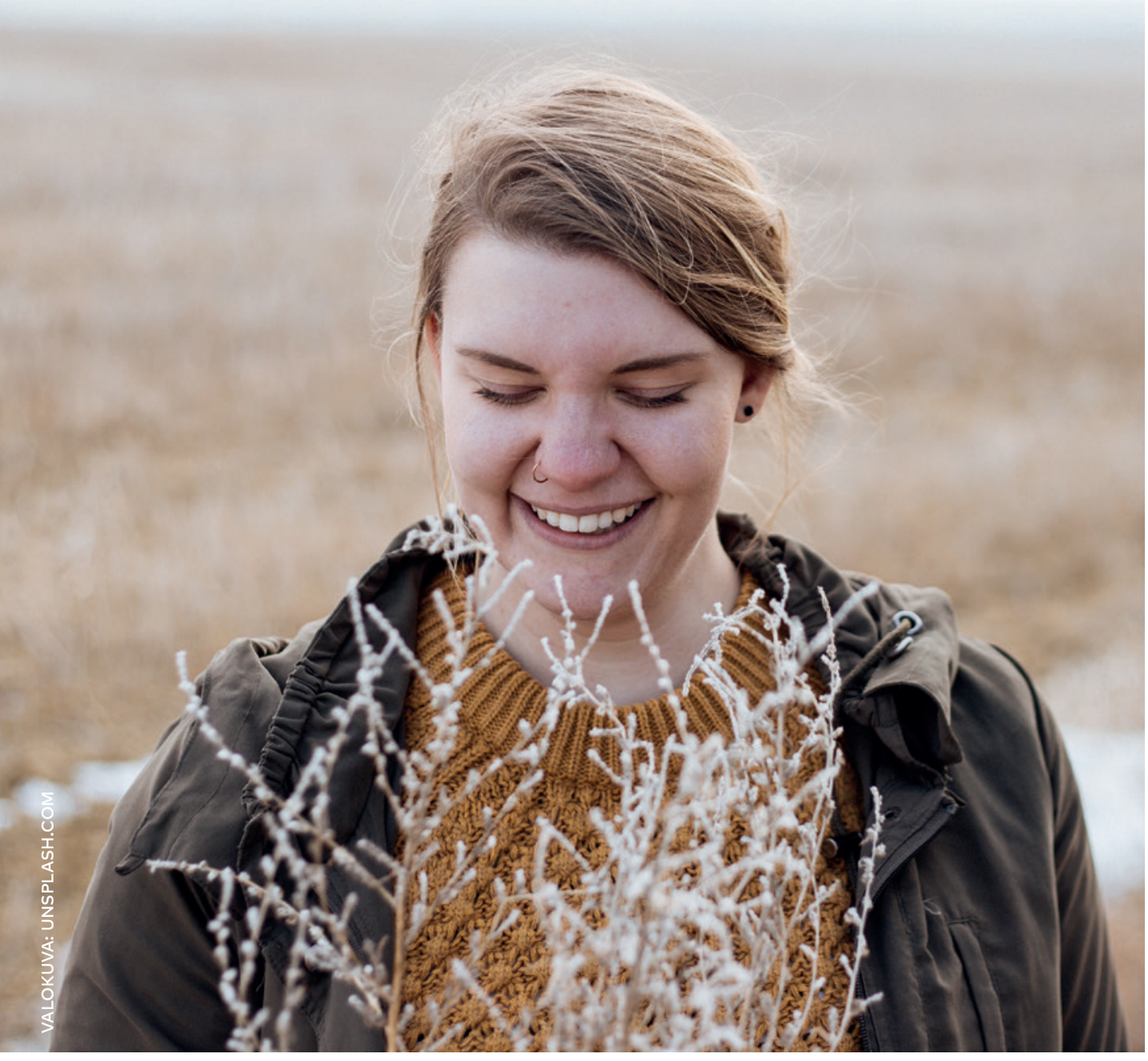




\section{Pohjoismaiden ministerineuvoston työ kestävän kehityksen tavoitteiden parissa}

Pohjoismaiset yhteistyöministerit (MR-SAM) tekivät vuonna 2016 periaatepäätöksen pohjoismaisen ohjelman käynnistämisestä kestävän kehityksen toimintaohjelman toteuttamiseksi. Pohjoismaiden ministerineuvoston sihteeristön tehtävänä on nyt laatia ohjelmaehdotus kestävän kehityksen pohjoismaisen asiantuntijaryhmän tuella. Ryhmä on pohjoismaisen yhteistyökomitean (NSK) alaisuudessa toimiva neuvoa-antava elin. Pohjoismaiden neuvosto sai työryhmän kautta mahdollisuuden kommentoida ministerineuvoston aineistoa ja alustavia tavoitteita.

MR-SAM hyväksyi ohjelmaehdotuksen syyskuussa 2017 pitämässään kokouksessa. Sukupolvi 2030 -nimen saanut ohjelma on käynnissä 2017-2020 ja se esitellään Pohjoismaiden neuvostolle ministerineuvoston ehdotuksena marraskuussa 2017. Ehdotuksen lähtökohtana ovat 17 kestävän kehityksen tavoitetta. Ohjelman kautta halutaan toteuttaa Pohjoismaiden ministerineuvoston kestävän kehityksen strategiaa Hyvä elämä kestävässä Pohjolassa vuodelta 2013.

Sukupolvi 2030 -ohjelmassa ajatuksena on keskittyä erityisesti kestävään kulutukseen ja tuotantoon viitaten kestävän kehityksen tavoitteeseen 12. Siinä viitataan lisäksi seuraaviin Pohjoismaille ja pohjoismaiselle yhteistyölle erityisen tärkeisiin tavoitteisiin: tasa-arvo (5), vesi (6), energia (7), työolot ja kasvu (8), ilmasto (13), meret (14) ja luonnon monimuotoisuus (15). Ohjelmassa korostetaan myös nuorten osallistamista sekä tasa-arvonäkökulman valtavirtaistamista. Kestävän kehityksen tavoitteiden sisällyttämiseksi työhön ehdotetaan poliittista huomiota ja ajankohtaisia hankkeita, osallisuutta ja tiedon jakamista Pohjoismaissa sekä Pohjoismaiden ministerineuvoston työn näkyvöittämistä Pohjoismaissa ja kansainvälisesti. Ohjelmakauden aikana työhön arvioidaan käytettävän 12,9 miljoonaa Tanskan kruunua. Lisäksi siihen saadaan muuta ministerineuvoston sisäistä rahoitusta. Ohjelman mukaan ministerineuvosto raportoi työn etenemisestä Pohjoismaiden neuvostolle joka toinen vuosi. Sukupolvi 2030 -ohjelma sisältää 10 ohjelmatavoitetta, mutta konkreettisia panostuksia ei kuvata.

Ministerineuvoston ehdotuksesta käy ilmi, että ohjelmaan tehdään mahdollisia tarkistuksia sen jälkeen, kun Pohjoismaiden neuvosto on käsitellyt asian. 


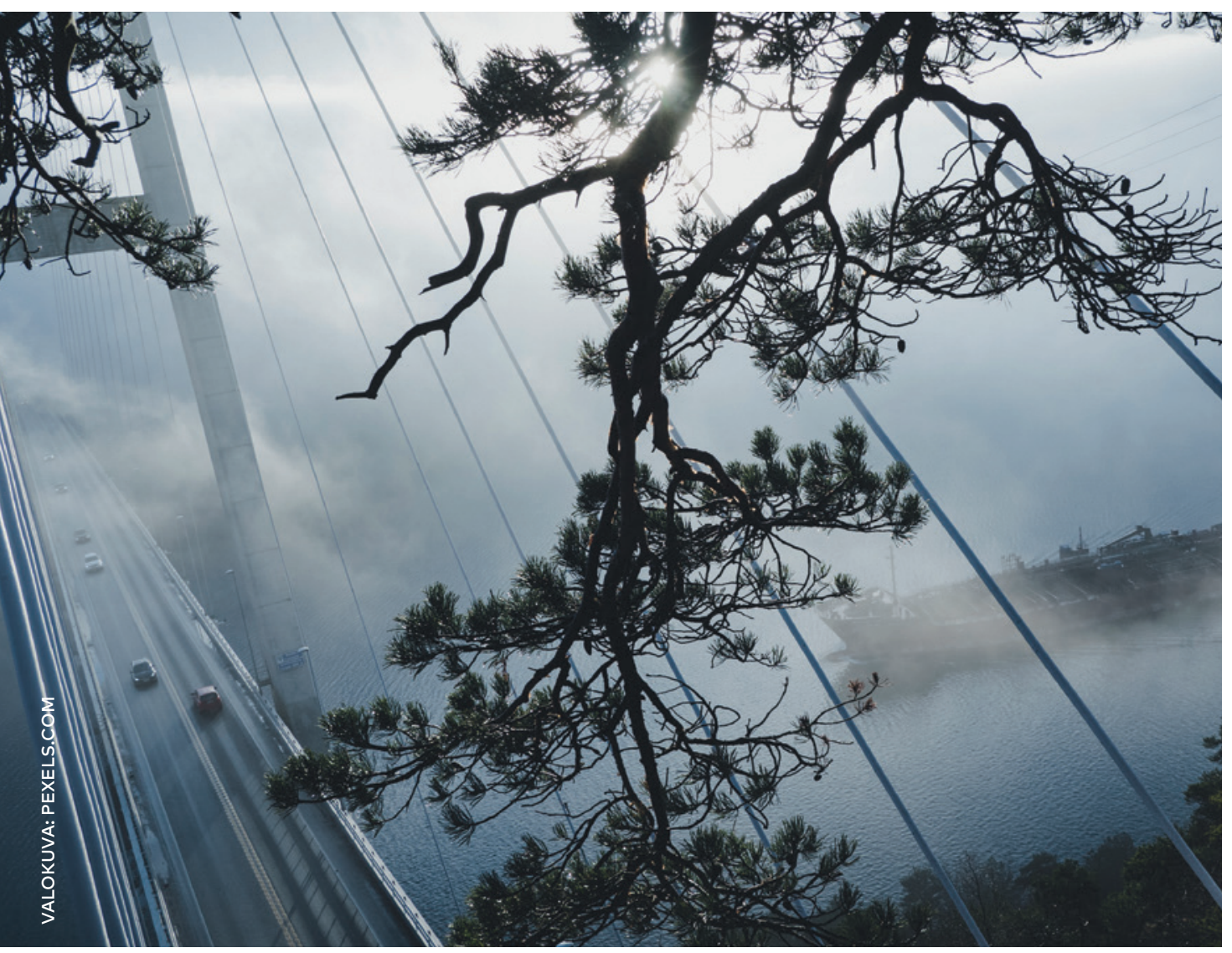

\section{YK:n 2030-tavoitteet yhteispohjoismaisina tavoitteina}

Hyväksytyt kestävän kehityksen tavoitteet, niin 17 yleistavoitetta kuin 169 alatavoitetta, ovat myös Pohjoismaiden tavoitteita. Jotkut tavoitteet ovat Pohjoismaille ajankohtaisempia kuin toiset. Pohjoismailla on maailmanlaajuisesti erittäin hyvä asema tavoitteiden osalta ja huippusijoitus kansainvälisissä vertailevissa tilastoissa. ${ }^{9}$
Pohjoismaiden ministerineuvoston nykyinen Hyvä elämä kestävässä Pohjolassa -strategia ${ }^{10}$ työlle kestävän kehityksen parissa määrittelee vuoteen 2025 ulottuvat tavoitteet ja indikaattorit kehityksen seuraamiseksi. Tavoitteet on jaettu viiteen eri osa-alveeseen ja niiden edistymistä mitataan indikaattoreilla: 
- Pohjoismainen hyvinvointimalli

- 9 indikaattoria

- Elinvoimaiset ekosysteemit

- 5 indikaattoria

- Muuttunut ilmasto - 3 indikaattoria

- Maapallon luonnonvarojen kestävä käyttö - 4 indikaattoria

- Koulutus, tutkimus ja innovaatiot -2 indikaattoria

Vuoteen 2030 ulottuvan kehityksen seuraamiseksi on järkevää pitäytyä nykyisissä indikaattoreissa ja tavoitteissa, jotka on asetettu Pohjoismaiden ministerineuvoston Hyvä elämä kestävässä Pohjolassa -strategiassa. Strategia on teknisen päivityksen tarpeessa ministerineuvoston uuden YK:n 2030-tavoiteohjelman osalta. Norden.org-sivustolla ${ }^{11}$ säännöllisesti päivitettävistä kestävän kehityksen indikaattoreista saatava hyöty kasvaa jatkuvasti. On myös perusteltua lisätä 169 alatavoitteesta Pohjoismaiden yhteisiksi tavoitteiksi ne, joiden osalta Pohjoismaat toteuttavat yhteisiä toimia tai suunnittelevat tulevaa yhteistyötä. Tällaisia ovat esimerkiksi alatavoite 12.3 ruokajätteen puolittamisesta ja 4.4 nuorten ammatillisen osaamisen ja työsaantimahdollisuuksien parantamisesta. Jotkin merten ekosysteemejä (14) ja maaekosysteemejä (15) käsittelevien tavoitteiden alatavoitteista soveltuvat Pohjoismaiden yhteisiksi tavoitteiksi ja liittyvät Pohjoismaiden ministerineuvostossa jo tehtävään vakiintuneeseen ja toimivaan yhteistyö- hön. Tällaisia ovat esimerkiksi alatavoite 14.1 merten saastumisen vähentämisestä maalta meriin päätyvien jätteiden ja ravinnekuormituksen kautta. Merten muovijätteet ovat vahvasti esillä, minkä vuoksi siitä voitaisiin kehittää Pohjoismaiden yhteinen erityistavoite. Luonnon monimuotoisuutta käsittelevät alatavoitteet 15.4 ja 15.5 voisivat myös olla ajankohtaisia Pohjoismaille yhteisiä tavoitteita.

Kuten 5. luvun koosteesta käy ilmi, Norja, Suomi, Tanska ja Ahvenanmaa ovat laatineet ja hyväksyneet YK:n 2030-tavoitteille kansalliset suunnitelmat, jotka kytkeytyvät suoraan tiettyihin (priorisoituihin) tavoitteisiin ja alatavoitteisiin sekä sisältävät tavoitteiden kehitysseurannan raportoinnin ja indikaattorien kautta. ${ }^{12}$ Muut Pohjoismaat seuraavat pian perässä. Voisi olla hyödyllistä laatia selvitys siitä, ovatko Pohjoismaat kansallisissa suunnitelmissaan painottaneet samoja tavoitteita. Sen pohjalta voitaisiin löytää yhteisiä aiheita ja päättää kaikille Pohjoismaille ajankohtaisista tavoitteista. 

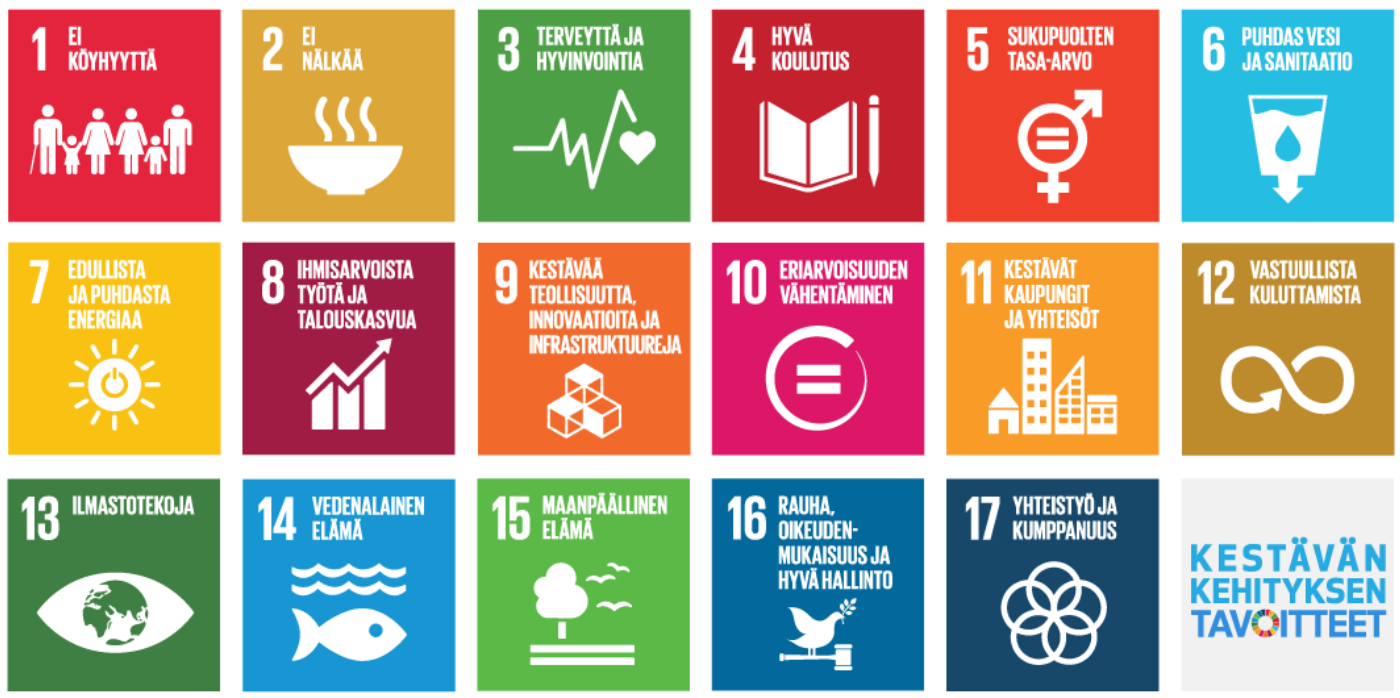
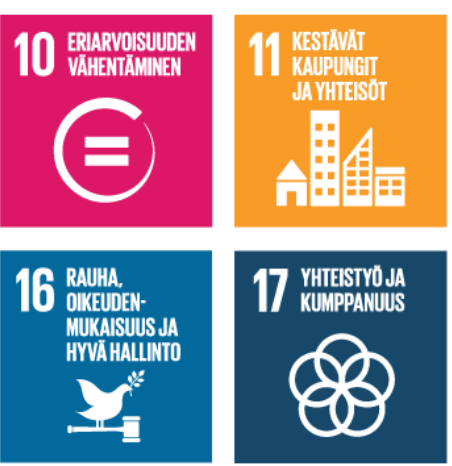

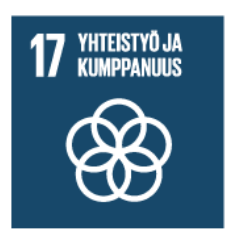

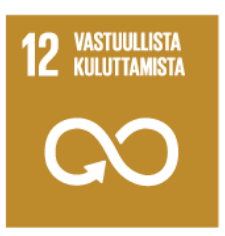

KESTÅVÅN KEHITYKSEN TAVOITEET

\section{Ryhmän suositukset}

\section{A. POHJOISMAIDEN NEUVOSTON SISÄINEN TYÖ}

\section{a1. YK:n 2030-tavoitteet osana neuvos- ton ja valiokuntien vuotuisia työsuunni- telmia}

Kestävän kehityksen 17 tavoitetta liittyvät kutakuinkin kaikkiin politiikan aloihin, joiden parissa Pohjoismaiden neuvosto työskentelee. Työryhmä ehdottaa, että valiokunnat jakavat vastuun tavoitteiden seurannasta alla esitetyn koosteen mukaisesti ja että vähintään yksi kunkin valiokunnan vastuulle asetetuista tavoitteista tai alatavoitteista kirjataan vuotuiseen työsuunnitelmaan. Pohjoismaiden neuvostolla ei ole yleistä työsuunnitelmaa, mutta Pohjoismaiden neuvoston puheenjohtajamaalla on tapana määritellä useita poliittisia priorisointeja. Pohjoismaiden neuvoston kansallisia valtuuskuntia kehotetaan jatkossa ottamaan huomioon kestävän kehityksen tavoitteet puheenjohtajakauden priorisoinneista päätettäessä.

Kestävä Pohjola -valiokunta Tavoite 2: Ei nälkää Tavoite 6: Puhdas vesi ja sanitaatio Tavoite 11: Kestävät kaupungit ja yhteisöt

Tavoite 13: Ilmastotekoja Tavoite 14: Vedenalainen elämä Tavoite 15: Maanpäällinen elämä

Hyvinvointi Pohjolassa -valiokunta Tavoite 1: Ei köyhyyttä Tavoite 3: Terveyttä ja hyvinvointia Tavoite 5: Sukupuolten tasa-arvo Tavoite 10: Eriarvoisuuden vähentäminen 
Osaaminen ja kulttuuri Pohjolassa

-valiokunta

Tavoite 4: Hyvä koulutus (liittyy

tavoitteeseen 1 köyhyyden poistamisesta)

Tavoite 16: Rauha, oikeudenmukaisuus ja hyvä hallinto

Kasvu ja kehitys Pohjolassa -valiokunta

Tavoite 7: Edullista ja puhdasta energiaa

Tavoite 8: Ihmisarvoista työtä ja talouskasvua

Tavoite 9: Kestävää teollisuutta, innovaatioita ja infrastruktuureja

Tavoite 12: Vastuullista kuluttamista

Puheenjohtajistolle olennainen tavoite on nro 17: Tuetaan vahvemmin kestävän kehityksen toimeenpanoa ja globaalia kumppanuutta. Kysymys voisi esimerkiksi sisältyä Pohjoismaiden ministerineuvoston kanssa vuosittain käytäviin budjettineuvotteluihin.

Kuten koosteesta käy ilmi, käsittelyssä on useita laaja-alaisia tavoitteita ja alatavoitteita. Pohjoismaiden neuvosto kokoontuu viisi kertaa vuodessa, minkä vuoksi voi olla vaikeaa käsitellä näin monia tavoitteita. On tärkeää jakaa työ koko ajanjaksolle 2018-2030, jotta tehtävästä ei muodostuisi liian laajaa hahmotettavaksi ja toteutettavaksi. Sen vuoksi ehdotetaan, että kukin valiokunta keskittyy priorisoituihin tavoitteisiin pyrkien samalla siihen, että vuoden 2030 lähestyessä tavoitteita olisi saatu käsiteltyä laajasti. Tavoitteita tulee myös käsitellä Pohjoismaiden ministerineuvoston vuotuiseen budjettiin liittyen.

Monet tavoitteet koskevat useita valiokuntia, kuten vastuullinen kuluttaminen
(12), edullinen ja puhdas energia (7) ja nälän poistaminen (2). Sen vuoksi suositellaan, että asianomaiset valiokunnat käsittelevät tavoitteita yhdessä tarpeen mukaan.

Vuosiksi 2017-2020 ehdotetaan seuraavia painopisteitä:

- Kestävä Pohjola -valiokunta Tavoite 14 ja toimet puhtaiden merialveiden edistämiseksi Pohjoismaissa

- Osaaminen ja kulttuuri Pohjolassa -valiokunta - Tavoite 4: hyvä koulutus ${ }^{13}$

- Hyvinvointi Pohjolassa -valiokunta Tavoite 10: eriarvoisuuden vähentäminen ja pohjoismainen malli

- Kasvu ja kehitys Pohjolassa -valiokunta - Tavoite 9: kestävää teollisuutta, innovaatioita ja infrastruktuureja, sekä pohjoismainen liikennesuunnitelma, joka yhdistää Pohjoismaat niin pitkittäis- kuin poikittaissuunnassa ja digitaaliset ratkaisut. ${ }^{14}$

Tavoitteiden toteuttamistyössä valiokuntia kehotetaan muotoilemaan tavoitteista mahdollisimman konkreettisia, jotta työn vaikutuksia voidaan mitata.

Pohjoismaiden neuvosto on hyväksynyt useita suosituksia, jotka ovat ajankohtaisia työssä kestävän kehityksen tavoitteiden parissa. Valiokuntien on syytä hyödyntää näitä poliittisia asiakirjoja tarpeen mukaan. Esimerkiksi Pohjoismaiden neuvoston päätös pohjoismaisesta valkoisesta kirjasta, jossa ehdotetaan toimia antibioottiresistens- 
sin torjumiseksi (huhtikuulta 2017), on erittäin ajankohtainen hyvää terveyttä käsittelevän tavoitteen 3 kannalta. Tuoreet suositukset toimista ruokahävikin vähentämiseksi (vuodelta 2016) ovat puolestaan ajankohtaisia nälän poistamista käsittelevän tavoitteen 2 kannalta. Pohjoismaiden neuvoston vastikään hyväksytty suositus muoviroskan vähentämisestä taas on erittäin ajankohtainen merten ekosysteemejä käsittelevän tavoitteen 14 kannalta.

\section{Pohjoismaiden neuvoston sihteeristön} tehtävänä on laatia aikataulu tulevien vuosien kokouksista tavoitteena turvata, että kaikki tavoitteet ehditään käsitellä järjestelmällisesti alatavoitteiden ja Pohjoismaiden nykyistä tilannetta koskevien tietojen osalta.

Tavoitteiden käsittely valiokunnissa voidaan toteuttaa kirjallisin raportein tai kuulemalla kyseisen alan asiantuntijoita. Valiokuntien tulee esitettyjen tietojen pohjalta muodostaa tilannekuva yleistavoitteen tai alatavoitteen saavuttamisesta ja siitä, tarvitaanko Pohjoismailta ja/tai Pohjoismaiden ministerineuvostolta lisätoimia kyseisen yleistavoitteen tai alatavoitteen saavuttamiseksi. Tulokset valiokuntien käsittelystä kootaan vuosittain asiakirjaksi, joka esitellään puheenjohtajiston joulukuun kokouksessa. Puheenjohtajisto voi tarpeen mukaan esittää kysymyksiä seurannan puutteesta yhteistyöministerien ja pääministerien kanssa pidettävissä kokouksissa.

\section{a2. Kaikki jäsen- ja valiokuntaehdotukset sekä ministerineuvoston ehdotukset arvioidaan suhteessa YK:n 2030-tavoitteisiin}

Pohjoismaiden neuvosto hyväksyy vuosittain noin 30 suositusta, jotka pohjautuvat jäsenehdotuksiin, valiokuntaehdotuksiin ja ministerineuvoston ehdotuksiin. Ehdotuksia käsitellään yleensä vähintään kahdessa asiasta vastaavan valiokunnan kokouksessa, ja monista järjestetään myös lausuntokierroksia. Käsittely suunnitellaan sihteeristön laatimien suuntaviivojen pohjalta. Ehdotuksena on, että kaikissa jäsenehdotuksista ja ministerineuvoston ehdotuksista laadittavissa mietinnöissä vastataan kysymykseen, liittyykö ehdotus yhteen tai useampaan kestävän kehityksen tavoitteeseen tai alatavoitteeseen. Jos näin on, otetaan kantaa siihen, voidaanko suosituksen toteuttamisen olettaa edistävän tai hankaloittavan kyseisen tavoitteen toteutumista.

\section{a3. Pohjoismaiden neuvosto Pohjolassa ja maailmassa}

Pohjoismaiden neuvosto osallistuu vuosittain moniin kansainvälisiin parlamentaarisiin kokouksiin esimerkiksi Benelux-parlamentissa, Baltian parlamentaarisessa yleiskokouksessa ja arktisen alveen parlamentaarikkojen yhteistyöelimessä (CPAR). Monissa näistä foorumeista käsitellään YK:n 2030-tavoitteiden seurannan kannalta ajankohtaisia aiheita. Työryhmä ehdottaa, että Pohjoismaiden neuvoston sihteeristö ottaa tavaksi tarkistaa, onko asialistan perusteella syytä ottaa esille YK:n 2030-tavoitteisiin liittyviä ehdotuksia näissä kansainvälisissä kokouksissa, ja tiedottaa kokouksiin osal- 
listuvia Pohjoismaiden neuvoston jäseniä asiasta.

Kestävän kehityksen tavoitteiden demokraattisen jalkauttamisen tulee tapahtua kansallisissa parlamenteissa.

Kuten 5. luvussa tuli esille, Norjan suurkäräjät osallistetaan kestävän kehityksen tavoitteiden toteuttamiseen budjettiprosessin kautta. Lisäksi todettiin, että eduskunnalla on aktiivinen rooli työn toteuttamisessa Suomessa. Muiden Pohjoismaiden osalta on epäselvää, millainen rooli kansallisilla parlamenteilla tulee olemaan kestävän kehityksen tavoitteiden toteutuksessa. Pohjoismaiden neuvosto voisi tehdä aloitteen pohjoismaisesta pyöreän pöydän konferenssista, jossa Pohjoismaiden parlamentit vaihtavat tietoa ja ajatuksia parlamenttien roolista kestävän kehityksen tavoitteiden toteuttamisessa.

\section{B. EHDOTUKSET POHJOISMAIDEN MINISTERINEUVOSTOLLE}

\section{b1. Elinkeinoelämän osallistaminen \\ Elinkeinoelämällä on tärkeä rooli työssä kestävän kehityksen tavoitteiden saa- vuttamiseksi, mikä käy selvästi ilmi YK:n päätöksestä. ${ }^{15}$ Sillä on valmiudet ja taloudelliset edellytykset edistää vihreää murrosta. Elinkeinoelämä voi kehittää liiketoimintamalleja ja markkinoita tuot- teilleen YK:n kestävän kehityksen tavoit- teiden mukaisesti: oikein toimimisen tulee olla kannattavaa. Pohjoismaisessa yhteistyössä on toteutettu useita aloit- teita vihreän murroksen edistämiseksi; menestyksen avaimina toimivat inno-}

vointi, riittävän rahoituksen saatavuus sekä resurssien parempi hyödyntäminen. Elinkeinoelämä on kiinnostunut työhön osallistumisesta, ja esimerkiksi Tanskan teollisuusalan etujärjestö Dansk Industri on julkaissut tanskankieliset suuntaviivat $^{16}$ yritysten työlle kestävän kehityksen tavoitteiden edistämiseksi.

Pohjoismaiden neuvosto vieraili YK:n Kööpenhaminan-toimitiloissa vuoden 2016 istunnon yhteydessä. Vierailun seurantana työryhmä on käynyt keskustelua YK:n kehitysohjelman UNDP:n kanssa ohjelmasta, jonka tavoitteena on lisätä elinkeinoelämän osallistumista työhön kestävän kehityksen tavoitteiden toteuttamiseksi. UNDP on esitellyt SDG-Acceleratorohjelman (SDGA), jota se haluaa testata Pohjoismaissa kolmen vuoden ajan yhteistyössä 150 yrityksen kanssa. Koekaudella kerättävien kokemusten pohjalta ohjelmaa voidaan laajentaa muille alveille. UNDP on esittänyt, että virallisen pohjoismaisen yhteistyön tuki SDGA-ohjelmalle edistäisi asiaa. Työryhmä suosittaa, että Pohjoismaiden ministerineuvoston asianomainen laitos, Nordic Innovation, selvittää mahdollisuuksia yhteistyöhön UNDP:n kanssa SDGA-ohjelman parissa. Yleisesti suositetaan, että kaikki elinkeinoelämän parissa työskentelevät pohjoismaiset laitokset, esimerkiksi Pohjoismainen energiantutkimus (NEF), Nordic Innovation, Pohjoismaiden ympäristörahoitusyhtiö (NEFCO) ja NordForsk, selvittävät tulevaa työtä suunnitellessaan, miten ne voisivat tukea YK:n 2030-tavoitteiden toteutumista. 
Ruotsin 20 suurinta yritystä on perustanut Swedish Leadership for Sustainable Development -foorumin (SLSD). Ryhmän sihteeristönä toimii Kansainvälisen kehitysyhteistyön keskusvirasto (Sida). On syytä selvittää, voitaisiinko tällaista aloitetta laajentaa tai viedä muihin Pohjoismaihin yhä useamman pohjoismaisen suuryrityksen mukaan saamiseksi.

\section{b2. Analyysit ja vuoropuhelu (kestävän kehityksen toimintaohjelman pohjoismainen foorumi)}

Vertailevien analyysien mukaan

Pohjoismailla on suhteellisen vahva asema kestävän kehityksen tavoitteiden saavuttamiseksi. Siitä huolimatta edessä on vaikea tehtävä määritellä, miten kukin tavoite ja alatavoite saavutetaan. Poliittisia ratkaisuja ei aina ole niin helppo löytää. Ehdotuksena on, että Pohjoismaiden ministerineuvosto perustaa yhteistyössä Pohjoismaiden neuvoston kanssa foorumin, jossa poliitikot ja tutkijat käyvät vuoropuhelua ratkaisuista, jotka pohjautuvat kaikkien eri Pohjoismaiden tutkimukseen ja tietotaitoon. Mahdollisena yhteistyökumppanina voisi toimia YK:n Sustainable Development Solutions Network (SDSN Northern Europe), jolla on sihteeristö Göteborgissa. Yhteistyön tavoitteena voisi olla selvittää pohjoismaista ja kansainvälistä tutkimusta ja osaamista, jota tarvitaan kestävän kehityksen tavoitteiden toteuttamiseksi Pohjoismaissa. Lisäksi voitaisiin pyrkiä antamaan poliitikoille mahdollisuus käydä keskustelua tutkimuksen tarjoamista vastauksista. Tämä voitaisiin toteuttaa vuotuisen kokouksen kautta otsikolla kestävän kehityksen toimintaohjelman pohjoismainen foorumi. Pohjoismaiden neuvostoa tulisi kuulla, jotta voidaan selvittää, mitkä YK:n 2030-tavoitteista pohjoismainen foorumi päättäisi ottaa käsiteltäväksi. Tilaisuuteen voisi osallistua asianomaisia pohjoismaisia ministereitä, Pohjoismaiden neuvoston jäseniä sekä Pohjoismaiden kansallisten parlamenttien edustajia.

\section{b3. Yhteiset tavoitteet ja indikaattorit} Ohjelman 17 yleistavoitteesta ja 169 alatavoitteesta tietyt ovat erittäin ajankohtaisia Pohjoismaiden sisällä ja toiset ovat ajankohtaisempia muvalla maailmassa. Äskettäin julkaistun analyysin mukaan Pohjoismaat johtavat 17 tavoitteen toteuttamisessa. Ruotsi on ensimmäisellä sijalla tavoitteet täyttävistä maista, ja muut Pohjoismaat seuraavat tiiviisti perässä. Norja, Suomi, Tanska ja Ahvenanmaa ovat jo määritelleet priorisoitavat tavoitteet seurattaviksi indikaattorien avulla, jotta olisi helpompi arvioida, onko kehityksen suunta toivottua.

Luvussa 7 kuvaillaan lyhyesti Pohjoismaiden ministerineuvoston nykyistä kestävän kehityksen strategiaa: Hyvä elämä kestävässä Pohjolassa. Strategiassa määritellään vuoteen 2025 ulottuvat tavoitteet. Siinä on lisäksi määritelty 23 indikaattoria, joiden avulla seurataan, eteneekö kehitys tavoitteiden mukaisesti.

Jatkokehityksen seuraamiseksi on järkevää pitäytyä nykyisissä indikaattoreissa ja tavoitteissa. On myös perusteltua 
lisätä 169 alatavoitteesta Pohjoismaiden yhteisiksi tavoitteiksi ne, joiden osalta Pohjoismaat toteuttavat yhteisiä toimia tai suunnittelevat tulevaa yhteistyötä. Tähän liittyviä ajatuksia esitellään 7. luvussa. Lisäksi viitataan tanskalaisen Sustainia-ajatushautomon Pohjoismaiden ministerineuvoston toimeksiannosta laatimaan muistioon. Sen lähtökohtana ovat useat vertailevat analyysit, joiden tavoitteena on tunnistaa Pohjoismaille yhteisiä haasteita, mukaan lukien keinolannoitteiden tehokkaampi käyttö Pohjoismaiden maataloudessa (tavoite 2), siirtyminen hiilineutraaliin energiahuoltoon (tavoitteet 7 ja 13), taloudellinen kasvu (tavoite 8), kestävä kulutus (tavoite 12) ja ekosysteemien suojelu (tavoitteet 14 ja 15).

Pohjoismaat ovat tehneet jo pitkään yhteistyötä tilastotiedon kehittämisessä ja julkaisemisessa. Pohjoismaiden tilastollinen vuosikirja on yksi Pohjoismaiden ministerineuvoston suosituimmista julkaisuista. Viime vuosina Pohjoismaiden ministerineuvosto on lisäksi julkaissut Pohjoismaiden kestävän kehityksen indikaattoreita. ${ }^{17}$ Suosituksena on, että Pohjoismaiden ministerineuvosto pitäytyy Hyvä elämä kestävässä Pohjolassa -strategian tavoitteissa, mutta että niitä täydennetään sellaisilla kestävän kehityksen tavoitteilla, jotka Pohjoismaat ovat valinneet yhteisiksi pohjoismaisiksi tavoitteiksi. Nykyiset kestävän kehityksen indikaattorit käydään läpi. Siltä osin kuin soveltuvia indikaattoreita ei ole, Pohjoismaiden tilastokeskuksille tulee antaa tehtäväksi kehittää tarvittavien tilastojen kokoamista ja työstämistä, jotta voidaan seurata asetettujen tavoitteiden toteutumista.

Pohjoismaiden ministerineuvoston tulee antaa säännöllisesti (kolmen vuoden välein, ensimmäisen kerran vuonna 2020) selonteko Pohjoismaiden neuvostolle indikaattorien kuvaamasta kehityksestä ja Pohjoismaiden ministerineuvoston käynnistämistä aloitteista tavoitteiden saavuttamiseksi. Selonteko voi toimia lähtökohtana Pohjoismaiden neuvoston täysistunnossa pidettävälle poliittiselle vuoropuhelulle Pohjoismaiden suunnasta kestävän kehityksen tavoitteiden saavuttamiseksi.

\section{b4. Muutokset eriarvoisuudessa ja Pohjoismaiden lasten elinoloissa} Lapset ovat keskeisellä sijalla kestävän kehityksen tavoitteissa - lähes kaikki tavoitteet voidaan kytkeä pyrkimykseen lasten arjen parantamisesta ja monet niistä liittyvät YK:n lapsen oikeuksien yleissopimukseen. Yhteinen tehtävä Pohjoismaille voisi olla arvioida säännöllisesti, miten muutokset ja erot vaikuttavat lapsiin ja heidän elinoloihinsa Pohjoismaissa ${ }^{18}$ tavoitteena vertailla olosuhteita, arvioida parannustarpeita ja oppia toisilta. Pohjoismainen yhteistyö pohjautuu samanlaisiin arvoihin ja yhteiseen kulttuuritaustaan. Käymällä säännöllisesti läpi sosiaalisten ja taloudellisten erojen vaikutuksia lapsiin saadaan paremmat edellytykset jakaa kokemuksia parhaista käytännöistä.

\section{b5. Pohjoismainen kolmikantakeskustelu} Vallitsee laaja yksimielisyys pohjoismaisen mallin hyödystä ja tarpeesta kehittää 
mallia sen elinkelpoisuuden säilyttämiseksi. Tämä edellyttää kovaa työtä. Pohjoismaisen mallin menestys pohjautuu vahvasti kussakin Pohjoismaassa käytävään rakentavaan ja säännölliseen kolmikantakeskusteluun, jossa valtio ja työmarkkinaosapuolet vaihtavat ajatuksia ja etsivät yhteisiä ratkaisumalleja.

Kunnollisten työolojen luominen Pohjoismaissa, vrt. tavoite 8 , on yhteispohjoismainen haaste, sillä kaikki Pohjoismaat ovat osa Euroopan yhteisiä työmarkkinoita. Sopeutuminen talouteen, jossa koneiden oletetaan jatkossa hoitavan monia matalasti koulutettujen työntekijöiden nykyisiä tehtäviä, edellyttää suurempaa panostusta osaamisen kehittämiseen. Osallistaminen, pudokkuuden ehkäiseminen ja tasa-arvo ovat esimerkkejä tehtävistä, joissa valtiot ja työmarkkinaosapuolet voisivat hyötyä yhteisistä toimista käyttökelpoisten ratkaisumallien löytymiseksi ja yhteiskunnan yhtenäisyyden turvaamiseksi.

Hyvinvointivaltion rahoittaminen verovaroin on vaikeutunut globalisaation lisääntyessä ja on esimerkki niistä haasteista, jotka soveltuisivat kolmikantakeskustelun aiheeksi pohjoismaisella tasolla. Pohjoismaissa ei kuitenkaan ole käynnissä kolmikantakeskustelua, jossa näihin haasteisiin voitaisiin pureutua. Sen vuoksi suosituksena on, että Pohjoismaiden ministerineuvosto selvittää edellytyksiä käynnistää kolmikantakeskustelua pohjoismaisella tasolla.

\section{b6. Tiedonvaihto parhaista käytännöistä}

Pohjoismaisessa yhteistyössä on ollut perinteenä vaihtaa tietoa ja kokemuk- sia, löytää parhaita käytäntöjä ja pyrkiä hyödyntämään tietyssä Pohjoismaassa toteutettujen toimien hyviä tuloksia laajemmin koko Pohjolassa. Viime aikoina on myös pyritty välittämään tietoa toimivista pohjoismaisista käytännöistä muihin maihin ja muille alveille. Yhtenä esimerkkinä on Pohjoismaiden pääministerien vuonna 2017 käynnistämä Nordic Solutions to Global Challenges -aloite, ${ }^{19}$ jonka tavoitteena on edistää kestävän kehityksen tavoitteiden saavuttamista. Toinen esimerkki on Nordic Climate Solutions -aloite, jota toteutetaan YK:n ilmastosopimuksen osapuolikokousten yhteydessä. Tämänkaltaisen toiminnan tulee sisältyä keskeisenä osana Pohjoismaiden ministerineuvoston ohjelmaan YK:n 2030-tavoitteiden toteuttamiseksi. Pohjoismaisten aloitteiden foorumina voisivat toimia myös vuotuiset YK:n korkean tason poliittiset foorumit (High-Level Political Forum, HLPF), joissa seurataan YK:n 2030-tavoitteiden toteutumista.

\section{b7. Pohjoismaiden kansalaisten tietämys ja osallistuminen}

Yksi onnistumisen edellytys YK:n 2030-tavoitteiden toteuttamisessa on lisätä tietoisuutta tavoitteista ja niiden tärkeydestä Pohjoismaiden väestön keskuudessa. Pohjoismaiden kansalaisjärjestöillä on perinteisesti ollut tärkeä asema välittää tietoa ja lisätä tietoisuutta uusista yhteiskuntatehtävistä. YK:n vuosituhattavoitteiden yhteydessä Norjan YK-liitto kehitti yhteistyössä pohjoismaisten sisarjärjestöjensä kanssa tietoportaalin YK:n vuosituhattavoitteista. Norden-yhdistykset ovat myös laatineet ja toteuttaneet ohjelmia 
tietoisuuden ja osallistumisen lisäämiseksi Pohjoismaiden kouluissa. YK:n 2030-tavoitteisiin kytkeytyvä jatkotyö voi pohjautua tähän ja muuhun tärkeään kokemukseen yhteistyöstä kansalaisjärjestöjen kanssa tiedon levittämisen parissa.

\section{b8. Pohjoismaisten rahoituslaitosten ${ }^{20}$ potentiaalin hyödyntäminen}

Vihreä murros sisältyy punaisena lankana moneen tavoitteeseen, mukaan lukien tavoite 7 puhtaasta energiasta, tavoite 8 taloudellisesta kasvusta, tavoite 12 vastuullisesta tuotannosta ja tavoite 13 ilmastosta. Vihreän murroksen edellytyksenä on rahoituksen saatavuus. Helsingissä sijaitsevat pohjoismaiset rahoitusyhtiöt ovat Pohjoismaiden Investointipankki (NIB), Pohjoismaiden ympäristörahoitusyhtiö (NEFCO, kattaa myös NOPEF-projektivientirahaston, joka aiemmin oli itsenäinen laitos) ja Pohjoismaiden kehitysrahasto (NDF). NIB on tehnyt useita onnistuneita sijoituksia ja yli 40 vuoden ajan rahoittanut kaupallisilla ehdoilla lukuisia infrastruktuuri-, energia-, ympäristö- ja teollisuushankkeita. NEFCO on 25-vuotisen toimintansa aikana saanut aikaan huomattavia ympäristöparannuksia Pohjolan lähialueille suuntautuvilla sijoituksillaan ja laajalla rahastohallinnollaan. NDF on saanut laajaa tunnustusta siitä lähtien, kun se vuodesta 2009 keskitti toimintansa köyhimpien maiden ilmastotyön tukemiseen. On tärkeää selventää näiden laitosten valtuuksia edistää kestävän kehityksen tavoitteiden toteuttamista. Lisäksi on tärkeää selvittää, onko laitoksissa laajempaa hyödyntämätöntä potentiaalia, joka voitaisiin saada Pohjoismaiden käyttöön joko yhdistämällä ne tai lisäämällä niiden välistä yhteistyötä.

\section{POHJOISMAIDEN YHTEINEN ÄÄNI EU:SSA, YK:SSA JA MUILLA KANSAINVÄLISILLÄ FOORUMEILLA}

YK:n kestävän kehityksen tavoitteet ovat osittain tulosta siitä, mitä Pohjoismaat ovat tuoneet esiin YK:ssa jo useiden vuosikymmenten ajan. Tätä sijoitusta on syytä vaalia jatkossakin, ei pelkästään YK:ssa vaan myös muissa keskeisissä organisaatioissa. Pohjoismaiden yhteinen ääni tuo enemmän painoarvoa kuin kunkin Pohjoismaan yksittäiset toimet. Pohjoismaisten asemien koordinointi suhteessa kansainvälisiin organisaatioihin voi tuottaa poliittista tulosta. Tämä on tosiasia ennen kaikkea EU:ssa, jossa useilla osa-alveilla laaditaan säännöstöjä YK:n 2030-tavoitteiden toteutuksen turvaamiseksi. Pohjoismaisen äänen tulee muun muassa puolustaa demokraattisia arvoja ja tasa-arvoa. Yleisesti ottaen Pohjoismaiden tulee puhua YK:n 2030-tavoitteiden mukaisen kehityksen puolesta varsinkin vuotuisissa YK:n korkean tason kokouksissa (HLPF), joissa seurataan YK:n 2030-tavoitteiden toteutumista. 


\section{Viitteet}

1. Tässä raportissa tavoitteita kutsutaan seuraavilla nimityksillä: kestävän kehityksen tavoitteet, YK:n 2030-tavoitteet, sustainable development goals (SDG) ja kestävän kehityksen toimintaohjelma (kun tarkoitetaan Agenda 2030 -toimintaohjelmaa).

2. Tehtävä kuuluu ennen kaikkea Pohjoismaiden kehitys- ja ulkopolitiikan vastuulle.

3. Tämä osio pohjautuu Gaia Consultingin ja Stockholm Environment Instituten Pohjoismaiden ministerineuvostolle laatiman Nordic implementation of the Global Agenda 2030 for Sustainable Development -raportin tietoihin.

4. National report on the implementation of the 2030 Agenda for Sustainable Development, Finland. Valtioneuvoston kanslian julkaisut, 10/2016.

5. Esimerkiksi vuoden 2017 tulo- ja menoarvion liitteenä on raportti Norjan YK:n kestävän kehityksen tavoitteiden seurannasta (Norges oppfølgning av FNs bærekraftsmål, Med. St. 1 Nasjonalbudsjett 2017).

6. Norway, initial steps towards the implementation of the 2030 agenda. Voluntary national review presented at the High-Level Political Forum on sustainable developmten (HLPF), UN, New York, July 2016.

7. Raportti: I riktning mot en hållbar välfärd - Agenda 2030-delegationens nulägesbeskrivning och förslag till handlingsplan för genomförandet av Agenda 2030 för hållbar utveckling till regeringen. 1.6.2017.

8. Sverige och Agenda 2030 - rapport till FN:s politiska högnivåforum 2017 om hållbar utveckling.

9. Ks. esim. SDG Index and Dashboards -raportti. Bertelsmann Stiftung, July 2017.

10. Hyvä elämä kestävässä Pohjolassa Kestävän kehityksen pohjoismainen strategia, Pohjoismaiden ministerineuvosto 2013.

11. Lukuja ja tilastoja, www.norden.org.

12. Kesäkuussa 2017 Ruotsissa toimiva komitea (Agenda 2030 -valtuuskunta) toimitti ehdotukset priorisoinneiksi.

13. Pöytäkirjaote Osaaminen ja kulttuuri Pohjolassa -valiokunnan kesäkokouksesta: "Valiokunta korosti erityisesti työtä tavoitteen 4 parissa: Taata kaikille avoin, tasa-arvoinen ja laadukas koulutus sekä elinikäiset oppimismahdollisuudet." 
14. Valiokunnan kesäkokouksen pöytäkirjassa lukee: "Pohjoismaiden digitalisaatioratkaisut voivat koitua myös köyhien maiden parhaaksi. Sen vuoksi tämä voisi olla hyvä panostusalue valiokunnalle."

15. YK:n kestävän kehityksen toimintaohjelman artiklassa 67 todetaan: "Private business activity, investment and innovation are major drivers of productivity, inclusive economic growth and job creation. We acknowledge the diversity of the private sector, ranging from micro enterprises to cooperatives to multinationals. We call on all businesses to apply their creativity and innovation to solving sustainable development challenges."

16. Johdannossa lukee muun muassa seuraavasti: "Kestävän kehityksen kompassi kuvaa, miten kestävän kehityksen tavoitteet vaikuttavat teidän yrityksenne toimintaan. Kompassi antaa välineitä ja tietoa, joiden avulla kestävyydestä voidaan tehdä vahva ydintekijä yrityksen strategiassa." Kestävän kehityksen tavoitteiden kompassi, Suuntaviivat yritysten työlle kestävän kehityksen tavoitteiden parissa. Julkaisu on käännös. Lisätietoa aiheesta on osoitteessa www.sdgcompass.org.

17. Pohjoismaiset kestävän kehityksen indikaattorit kuvaavat pitkän aika- välin kehitystä seuraavilla painopistealveilla: pohjoismainen hyvinvointimalli, elinvoimaiset ekosysteemit, muuttunut ilmasto, maapallon luonnonvarojen kestävä käyttö sekä koulutus, tutkimus ja innovaatiot.

18. Tämä voitaisiin toteuttaa esimerkiksi vuosina 2019, 2025 ja 2030. Islannin Unicef on laatinut vastaavan analyysin Islannissa, vrt. Staða barna á Íslandi 2011 -raportti.

19. Pohjoismaiden pääministerit julkistivat toukokuussa 2017 Nordic Solutions to Global Challenges -ohjelman, jonka parissa toteutetaan kolmen vuoden aikana kuusi kansainvälistä lippulaivahanketta. Ne tuovat esiin vuosina 2017-2019 pohjoismaisia kokemuksia, ratkaisuja ja näkemyksiä sopivissa kansainvälisissä yhteyksissä. Kolmivuotinen aloite rahoitetaan pääosin yhteispohjoismaisista budjettivaroista. Toistaiseksi hankkeeseen on varattu 74 miljoonaa Tanskan kruunua (noin 10 miljoonaa euroa), mutta summa voi vielä kasvaa.

20. NIB, NEFCO ja NDF eivät ole Pohjoismaiden ministerineuvoston alaisia laitoksia. Sen vuoksi niitä koskeva mahdollinen suositus suunnataan Pohjoismaiden hallituksille. 


\section{Työryhmän jäsenet}

- Sonja Mandt, puheenjohtajisto, puheenjohtaja

- Christian Juul, Hyvinvointi

Pohjolassa -valiokunta

- Hanna Kosonen, Kestävä

Pohjola -valiokunta

- Torgeir Knag Fylkesnes, Kasvu ja kehitys Pohjolassa -valiokunta

- Norunn Tveiten Benestad, Osaaminen ja kulttuuri

Pohjolassa -valiokunta
- Espen Krogh, Nuorten

Pohjoismaiden neuvoston presidentti.

Maat, jotka eivät olleet edustettuina työryhmässä, kutsuttiin myös osallistumaan. Färsaarilta ryhmään nimettiin Jenis av Rana ja Ahvenanmaalta Mikael Staffas. 


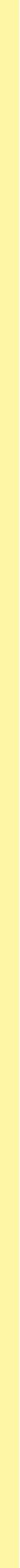


Pohjoismaiden neuvosto

Nordens Hus

Ved Stranden 18

1061 København K

www.norden.org

Syksyllä 2016 Pohjoismaiden neuvosto päätti asettaa valiokuntien ja puheenjohtajiston edustajista koostuvan työryhmän tarkoituksena selvittää Pohjoismaiden neuvoston edellytyksiä edistää YK:n

2030-tavoitteiden toteutumista ja laatia sitä koskevia ehdotuksia.

Työryhmän tehtävänä oli selkeyttää sitä, minkä tavoitteiden parissa

Pohjoismaat voivat tehdä yhteistyötä ja mitä toimia voitaisiin

käynnistää tavoitteiden saavuttamiseksi. Työryhmän jäseniä olivat puheenjohtajiston edustaja ja ryhmän puheenjohtaja Sonja Mandt, Hyvinvointi Pohjolassa -valiokunnan edustaja Christian Juul, Kestävä Pohjola -valiokunnan edustaja Hanna Kosonen, Kasvu ja kehitys Pohjolassa -valiokunnan edustaja Torgeir Knag Fylkesnes, Osaaminen ja kulttuuri Pohjolassa -valiokunnan edustaja Norunn Tveiten Benestad ja Nuorten Pohjoismaiden neuvoston presidentti Espen Krogh. 